\title{
Review
}

\section{Diagnosis of SARS-CoV-2: A review on the current scenario and future outlook}

\author{
PRIYANKA', O. P. CHOUDHARY², I. SINGH ${ }^{3}$
}

\begin{abstract}
${ }^{1}$ Department of Veterinary Microbiology, College of Veterinary Sciences and Animal Husbandry, Central Agricultural University (I), Jalukie, Peren-797110, Nagaland, India; ${ }^{2}$ Department of Veterinary Anatomy and Histology, College of Veterinary Sciences and Animal Husbandry, Central Agricultural University (I), Selesih, Aizawl-796015, Mizoram, India; ${ }^{3}$ Medical Superintendent, Community Health Centre, Deoband, Saharanpur-247554, Uttar Pradesh, India
\end{abstract}

Received June 6, 2020; accepted June 15, 2020

\begin{abstract}
Summary. - The novel severe acute respiratory syndrome coronavirus 2 (SARS-CoV-2) has undoubtedly created an emerging disease of topmost public health priority spilling throughout the globe. The diagnosis currently relies on a multiplex of criteria including the epidemiology, clinical manifestations and in vitro diagnostics. Presently, the real-time reverse transcriptase-PCR (rRT-PCR) is considered as the most reliable assay for the detection of SARS-CoV-2 and is being supplemented by other auxiliary tests, including serology and radiology. Many of these molecular and immunological tests have been validated by the Indian Council of Medical Research (ICMR) and the Food and Drug Administration (FDA) and commercial kits have been introduced in the field. But, considering the sensitivity and specificity based shortcomings and the lacunae in monitoring the spread of the virus, there is an immense need to develop integrated smart devices based on novel, safe, rapid and accurate diagnostic techniques and implement them on a large scale to curb this outbreak in the country and the world as a whole.
\end{abstract}

Keywords: clinical manifestations; COVID-19; diagnosis; PCR; SARS-COV-2; serology

\section{Introduction}

E-mail: priyanka7malik@gmail.com; phone: +91-8890650140, +91-9928099090.

Abbreviations: ARDS = acute respiratory distress syndrome; CLIA = chemiluminescence immunoassay; $\mathrm{CoV}=$ coronavirus(es); COVID-19 = coronavirus disease 2019; CT = computed tomography; ELISA = enzyme-linked immunosorbent assay; EUA = Emergency Use Authorization; FDA = Food and Drug Administration; ICMR = Indian Council of Medical Research; Ig = immunoglobulin; LFIA = lateral flow immunoassay; MERS = Middle East respiratory syndrome; $\mathrm{POCT}$ = point-of-care testing; $\mathrm{PPE}=$ personal protective equipment; $\mathrm{RdRp}=\mathrm{RNA}$-dependent RNA polymerase; $r R T-P C R=$ real-time reverse transcriptasePCR; SARS = severe acute respiratory syndrome; SARS-CoV-2 = SARS coronavirus 2; $\mathrm{VTM}=$ viral transport medium; $\mathrm{WHO}=$ World Health Organization
In the last two decades, the coronaviruses (CoV) have become the major pathogens of emerging respiratory disease epidemics such as the severe acute respiratory syndrome (SARS) in 2002 (China) and the Middle East respiratory syndrome (MERS) in 2012. The most recent outbreak of a novel coronavirus in the timeline began in 2019 with published literature tracing the first report of symptomatic individuals in Wuhan, China, in the form of pneumonia of unknown etiology. The International Committee on Taxonomy of Viruses (ICTV) termed it the SARSCoV-2 virus as it is very similar to the one that caused the SARS outbreak (SARS-CoV) (Cascella et al., 2020).

The SARS-CoV-2 is a positive-sense, single-stranded RNA virus which belongs to the genus Betacoronavirus 
of the Coronaviridae family (order Nidovirales). The WHO has designated the disease caused by this novel CoV as coronavirus disease 2019 (COVID-19) and it was declared as a public health emergency of international concern (PHEIC) on January 30, 2020 and a pandemic on March 11, 2020(Vashist et al.,2020). Till date, a total of 6703095 cases have been reported globally to be positive for SARS-CoV-2 with a case fatality rate of approximately 5.86\% (COVID-19 Coronavirus Pandemic, 2020); while in India, there are 227 029 confirmed cases with a case fatality rate of $2.80 \%$ as on $4^{\text {th }}$ June, 2020 (COVID-19 Coronavirus Pandemic, 2020). Among the various strategies which are being followed to contain the spread of this highly contagious virus in human population throughout the globe, there is an urgent need for prompt and intensive testing of suspected cases to diagnose SARS-CoV-2 so that quarantine measures can be taken and further spread of infection can be controlled.

\section{Diagnosis of SARS-CoV-2}

Clinical diagnosis of SARS-CoV-2 is mainly based on epidemiological history, clinical manifestations and some auxiliary examinations, such as CT scan, nucleic acid detection, blood culture and immunological techniques pointof-care testing (POCT) of IgM/IgG, ELISA (Li et al., 2020c).

\section{History}

A detailed history should be taken from the persons suspected to be infected with SARS-CoV-2, including the residence, travel, smoking and underlying comorbidities. The details of the important risk factors which should be recorded for suspicion of SARS-CoV-2 infection include the following:

- Fever and at least one respiratory manifestation such as cough or dyspnoea (WHO, 2020a).

- History of travel or residence in a geographical region reported to have community transmission of the SARSCoV-2 during the 14 days prior to the onset of symptoms (WHO, 2020a).

- Close contact with a suspected or confirmed person infected with SARS-CoV-2 during the 14 days prior to the onset of symptoms (WHO, 2020a).

- People aged 65 years and older are at higher risk of severe illness (Centers for Disease Control and Prevention, 2020).

- People with underlying health conditions i.e. comorbidities (e.g. chronic respiratory disease, cardiovascular disease, immunocompromised, obesity, diabetes, renal or liver disease, cancer) are at higher risk for severe illness (Centers for Disease Control and Prevention, 2020).
- Smokers are having 1.91 times the odds of progression in the severity compared to those who have never smoked (Patanavanich and Glantz, 2020).

- Severe disease and higher mortality has been seen in the male sex (Goyal et al., 2020; Zheng et al., 2020).

Testing certain asymptomatic individuals may also be important for infection control purposes (for e.g., in congregate settings where COVID-19 cases have been identified, prior to time-sensitive surgical procedures, and prior to time-sensitive aerosol-generating procedures if PPE (personal protective equipment) supplies are limited, and in hospitalized patients at locations where prevalence is high (McIntosh, 2020).

\section{Clinical manifestation}

The clinical spectrum of SARS-CoV-2 infection ranges from asymptomatic or paucisymptomatic forms to clinical conditions characterized by respiratory failure, to systemic manifestations in terms of sepsis, septic shock, and multiple organ dysfunction syndromes (Cascella et al., 2020). The prodromal symptoms on the initial presentation include fever, myalgia, cough and sore throat, which can become severe, and patients can flinch with shortness of breath and respiratory failure (Gupta et al., 2019). The incubation period for COVID-19 is thought to be within 14 days following exposure (Chan et al., 2020; Guan et al., 2020; Li et al., 2020a). Based on a modelling study from China, it has been estimated that symptoms develop in $97.5 \%$ of infected individuals within 11.5 days, with a median of 5.1 days (Lauer et al., 2020).

As per a report from the Chinese Center for Disease Control and Prevention that included approximately 44 500 confirmed infections, approximately $81 \%$ of patients presented mild illness, $14 \%$ presented severe illness, and $5 \%$ presented a critical illness (Wu and McGoogan, 2020). The characteristics of the various forms are given below:

\section{a. Asymptomatic form}

Though the precise frequency of asymptomatic infections is still unpredictable, but these have been well-documented in the literature (Chan et al., 2020; Gudbjartsson et al., 2020; Kimball et al., 2020; Liu et al., 2020b; Mizumoto et al., 2020; Sutton et al., 2020; WHO, 2020a). Screening of a cruise ship for SARS-CoV-2 revealed $17 \%$ of positive cases up to February 2020, half of which were not showing any clinical symptoms at the time of diagnosis and $18 \%$ of these were estimated to be true asymptomatic cases i.e. did not develop the symptoms subsequently (Mizumoto et al., 2020). Substantially higher proportions of asymptomatic forms have also been recorded. Screening of pregnant women at New York revealed 33 positive cases by the SARS-CoV-2 reverse transcription-PCR (RT-PCR) 
test on a nasopharyngeal specimen, 29 (88\%) of which were asymptomatic on presentation (Sutton et al., 2020).

b. Mild form

The mild form of the SARS-CoV-2 infection may present with symptoms including dry cough, mild fever, nasal congestion, sore throat, headache, muscle pain, and malaise, most of which are related to the upper respiratory tract (Cascella et al., 2020). Radiograph features are also absent in mild cases (Wang et al., 2020). This form can progress to more severe forms as well.

\section{c. Moderate form}

The respiratory symptoms evident in the moderate form include cough, shortness of breath, and tachypnoea (Cascella et al., 2020).

\section{d. Severe form}

This form is characterized by fever, severe dyspnoea, respiratory distress, tachypnoea ( $>30$ breaths $/ \mathrm{min}$ ), and hypoxia ( $\mathrm{SpO} 2<90 \%$ on room air). This is associated with severe pneumonia, acute respiratory distress syndrome (ARDS), sepsis, and septic shock (Cascella et al., 2020). ARDS can be suggestive of the onset of respiratory failure. Based on the degree of hypoxia, ARDS can be mild (200 $\mathrm{mmHg}<\mathrm{PaO} 2 / \mathrm{FiO} 2 \leq 300 \mathrm{mmHg})$, moderate $(100 \mathrm{mmHg}$ $<\mathrm{PaO} 2 / \mathrm{FiO} 2 \leq 200 \mathrm{mmHg})$ or severe $(\mathrm{PaO} 2 / \mathrm{FiO} 2 \leq 100$ $\mathrm{mmHg}$ ) (Cascella et al., 2020).

\section{e. Critical form}

If the disease progresses to critical form, it may result in respiratory failure, septic shock and/or multiple organ dysfunction (MOD) or failure (MOF). Data from the Chinese CDC regarding 72314 case records suggest that approximately $49 \%$ of the critical patients and those affected by pre-existing comorbidities such as cardiovascular disease, diabetes, chronic respiratory disease, and oncological diseases, died (Wu and McGoogan, 2020).

The clinical pictures of patients with COVID-19 induced sepsis have multiorgan involvement. These signs and symptoms include respiratory manifestations such as severe dyspnoea and hypoxemia, renal impairment with reduced urine output, tachycardia, altered mental status, and functional alterations of organs expressed as laboratory data of hyperbilirubinemia, acidosis, high lactate, coagulopathy, and thrombocytopenia. The reference for the evaluation of multiorgan damage and the related prognostic significance is the Sequential Organ Failure Assessment (SOFA) score, which predicts ICU mortality based on lab results and clinical data (Seymour et al., 2019). A pediatric version of the score has also received validation (Matics and Sanchez-Pinto, 2017). The septic shock is associated with increased mortality, circulatory, and cellular/metabolic abnormalities such as serum lactate level greater than $2 \mathrm{mmol} / \mathrm{l}(18 \mathrm{mg} / \mathrm{dl})$ and persisting hypotension despite volume resuscitation (Cascella et al., 2020). Some laboratory findings associated with the criti- cal illness include an exuberant inflammatory response, similar to cytokine release syndrome, with persistent fevers, elevated inflammatory markers (e.g. D-dimer, ferritin), and elevated proinflammatory cytokines (Huang et al., 2020a; Mehta et al., 2020).

Other complications include arrhythmias, acute cardiac injury, and shock (Arentz et al., 2020; Cao et al., 2020; Chen et al., 2020a; Wang et al., 2020). The onset of Guillain-Barré syndrome has also been reported 5 to 10 days after initial symptoms (Toscano et al., 2020). Smell and taste disorders (anosmia and dysgeusia) have also been reported in patients infected with SARS-CoV-2 (Giacomelli et al., 2020; Lechien et al., 2020). Gastrointestinal symptoms (eg, nausea and diarrhea) have also been reported, sometimes even on initial presentation (Goyal et al., 2020; Huang et al., 2020a; Jin et al., 2020; Wang et al., 2020). The prevalence of diarrhea, nausea/vomiting, and abdominal pain have been reported to be 13,10 , and 9 percent, respectively (Cheung et al., 2020b). Various other symptoms have also been reported, including headache, sore throat, and rhinorrhea (Chen et al., 2020a; Guan et al., 2020) and conjunctivitis (Colavita et al., 2020). In addition to such symptoms, there have also been reports of dermatologic findings, including maculopapular, urticarial, and vesicular eruptions and transient livedo reticularis (Casas et al., 2020; Galván et al., 2020; Manalo et al., 2020; Recalcati et al., 2020).

The clinical features which are apparent in the symptomatic SARS-CoV-2 infection are shown in Fig. 1.

\section{Laboratory features}

The laboratory examinations which should be conducted in the patients suffering from a severe form of SARS-CoV-2 infection have been compiled in Table 1. Among these, the laboratory abnormalities which are most commonly found in patients with pneumonia include lymphopenia, leukocytosis, thrombocytopenia, elevated liver transaminases, elevated C-reactive protein, elevated lactate dehydrogenase, etc. apart from neutrophilia, decreased haemoglobin, decreased albumin and renal impairment (Chen et al., 2020b; Goyal et al., 2020; Huang et al., 2020a; Li et al., 2020b; Qin et al., 2020; Wang et al., 2020). In children, these are not common (Garazzino et al., 2020).

\section{Sample collection}

The collection of samples in adequate quantity by proper methods is essential for the accurate diagnosis of SARS-CoV-2 infection. Table 2 shows the information on the collection and storage of samples from the presumably infected persons. If only one sample is to 


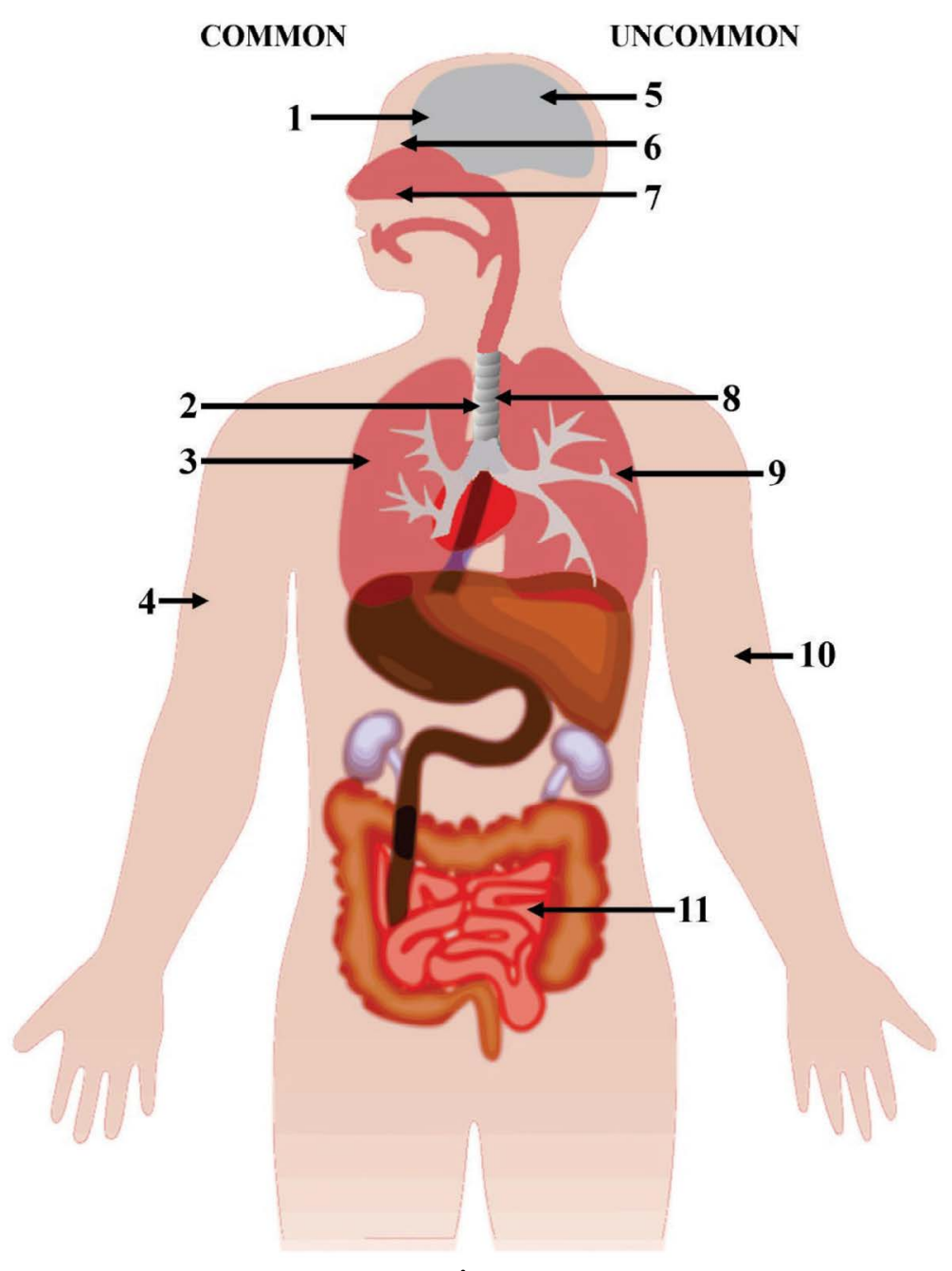

Fig. 1

Clinical manifestations of symptomatic SARS-CoV-2 infection in humans

Commonly evident symptoms include fever, altered sense of smell and/or taste(1), cough, sputum expectoration, sore throat (2), dyspnoea (3), fatigue, myalgia (4); whereas the uncommon symptoms include confusion, dizziness, headache (5), conjunctivitis (6), rhinorrhoea, nasal congestion (7), haemoptysis (8), chest pain, bronchial breath sounds, tachypnoea, crackles/rales on auscultation (9), cutaneous manifestations, cyanosis (10), and gastrointestinal symptoms (11).

be collected, the nasopharyngeal swab is recommended (Hong et al., 2020).

For the patients which are asymptomatic or have mild manifestations, the nasopharyngeal and oropharyngeal swabs should be collected and placed in the viral transport medium (VTM) to increase sensitivity (Centers for Disease Control and Prevention 2020; WHO, 2020a). If the sample from the upper respiratory tract of patients is negative, especially in patients with severe disease, samples from the lower respiratory tract should be tested for confirmation. As the serological tests become available, the paired serum samples (acute and convalescent) can be collected. Additional samples like blood, stool and urine may be collected, but the frequency of shedding of virus and hence the diagnostic value of such samples is still unknown. The samples should be transported to the laboratory at $2-8^{\circ} \mathrm{C}$ or; at $-70^{\circ} \mathrm{C}$ on dry ice in case of delay. In the laboratory, samples can be stored at $2-8^{\circ} \mathrm{C}$, but repeated freezing and thawing should be avoided (WHO, 2020a).

Note: As adapted from the guidelines on response to coronavirus disease 2019 published by the Korea Centers of Disease Control and Prevention (Korea Centers of Disease Control and Prevention, 2020), the cases can be defined as "confirmed case" as per the diagnostic criteria (positive for COVID-19 rRT-PCR, virus isolation) irrespective of clinical manifestations; and "suspected case" which is under scanner as per the clinical and epidemiological findings, but not yet confirmed. 
Table 1. Laboratory findings associated with SARS-CoV-2 infection (adapted from Beeching et al., 2020)

\begin{tabular}{|c|c|c|}
\hline Test & Results & Relevance \\
\hline Pulse oximetry & $\begin{array}{l}\text { Low oxygen saturation } \\
\left(\mathrm{SpO}_{2}<90 \%\right) \text { may be seen. }\end{array}$ & $\begin{array}{l}\text { Recommended in case of respiratory distress and cyanosis. Although 'silent } \\
\text { hypoxia' and respiratory failure can also occur in patients without any symp- } \\
\text { toms of respiratory distress (Xie et al., 2020). }\end{array}$ \\
\hline $\begin{array}{l}\text { Arterial blood } \\
\text { gas }(\mathrm{ABG})\end{array}$ & $\begin{array}{l}\text { Low partial oxygen pressure may } \\
\text { be seen. }\end{array}$ & $\begin{array}{l}\text { Recommended in case of respiratory distress and cyanosis in patients having } \\
\text { low oxygen saturation }\left(\mathrm{SpO}_{2}<90 \%\right) \text { to detect hypercarbia or acidosis. }\end{array}$ \\
\hline $\begin{array}{l}\text { Complete blood } \\
\text { count }(\mathrm{CBC})\end{array}$ & $\begin{array}{l}\text { Lymphopenia, leukocytosis, and } \\
\text { thrombocytopenia are most com- } \\
\text { monly seen. } \\
\text { Neutrophilia and decreased hae- } \\
\text { moglobin may be seen (Chen et al., } \\
\text { 2020; Huang et al., 2020; Qin et al., } \\
\text { 2020; Wang et al., 2020). }\end{array}$ & $\begin{array}{l}\text { Lymphopenia, leukocytosis, and thrombocytopenia may serve as markers for } \\
\text { early identification of severe disease associated with poor prognosis (Huang } \\
\text { et al., 2020; Tan et al., 2020). } \\
\text { High neutrophil-to-lymphocyte ratio also indicates the risk for severe illness } \\
\text { and poor prognosis (Lagunas-Rangel et al., 2020; Liu et al., 2020). }\end{array}$ \\
\hline $\begin{array}{l}\text { Coagulation } \\
\text { test }\end{array}$ & $\begin{array}{l}\text { Elevated D-dimer and fibrinogen, } \\
\text { prolonged prothrombin time (Chen } \\
\text { et al., 2020; Huang et al., 2020; Micco } \\
\text { et al., 2020; Wang et al., 2020). }\end{array}$ & $\begin{array}{l}\text { Non-survivors have been found to have significantly higher D-dimer levels, lon- } \\
\text { ger activated partial thromboplastin time and prothrombin time as compared } \\
\text { to survivors (Tang et al., 2020). }\end{array}$ \\
\hline Metabolic tests & $\begin{array}{l}\text { Elevated liver transaminases; } \\
\text { decreased albumin; renal impair- } \\
\text { ment (Chen et al., 2020; Huang et al., } \\
\text { 2020). }\end{array}$ & $\begin{array}{l}\text { Abnormalities in liver function may be more common in patients with SARS- } \\
\text { CoV-2 infection as compared to other types of pneumonia (Zhao et al., 2020). }\end{array}$ \\
\hline $\begin{array}{l}\text { Serum } \\
\text { procalcitonin }\end{array}$ & May be elevated. & $\begin{array}{l}\text { May be elevated in case of secondary bacterial infections (Huang et al., 2020; } \\
\text { Chen et al., 2020), more commonly in children (Xia et al., 2020). May be useful } \\
\text { in limiting the overuse of antibiotics in SARS-CoV-2 related pneumonia (Metlay } \\
\text { and Waterer, 2020). }\end{array}$ \\
\hline $\begin{array}{l}\text { Serum C-reac- } \\
\text { tive protein }\end{array}$ & May be elevated. & $\begin{array}{l}\text { May be elevated in case of secondary bacterial infections, or in hyper inflam- } \\
\text { mation (Huang et al., 2020; Chen et al., 2020). } \\
\text { May serve as markers for early identification of severe disease (Tan et al., 2020). }\end{array}$ \\
\hline Serum ferritin & May be elevated. & Indicates the development of cytokine release syndrome (Mehta et al., 2020). \\
\hline $\begin{array}{l}\text { Serum lactate } \\
\text { dehydrogenase }\end{array}$ & May be elevated. & $\begin{array}{l}\text { Reported in } 73 \% \text { to } 76 \% \text { cases (Chen et al., } 2020 \text {; Huang et al., 2020). May be more } \\
\text { common in patients with SARS-CoV-2 infection as compared to other types of } \\
\text { pneumonia (Zhao et al., 2020). }\end{array}$ \\
\hline $\begin{array}{l}\text { Serum creatine } \\
\text { kinase }\end{array}$ & May be elevated. & $\begin{array}{l}\text { Reported in } 13 \% \text { to } 33 \% \text { cases (Chen et al., 2020; Huang et al., 2020). Indicates } \\
\text { muscle or myocardium injury. }\end{array}$ \\
\hline Serum troponin & May be elevated. & Elevated in case of cardiac injury (Huang et al., 2020; Gupta et al., 2020). \\
\hline
\end{tabular}

Table 2. Collection and storage of samples (adapted from Druce et al., 2011)

\begin{tabular}{|c|c|c|c|}
\hline Sample type & Collection devices & Storage and shipment & Collection time \\
\hline $\begin{array}{l}\text { Upper respiratory tract } \\
\text { Nasopharyngeal swabs } \\
\text { Oropharyngeal swabs } \\
\text { Nasopharyngeal wash }\end{array}$ & $\begin{array}{l}\text { Dacron or polyester flocked } \\
\text { swabs*. } \\
\text { Sterile container*. }\end{array}$ & $\begin{array}{l}2-8^{\circ} \mathrm{C} \text { within } 5 \text { days; } \\
-70^{\circ} \mathrm{C} \text { for more than } 5 \text { days. } \\
2-8^{\circ} \mathrm{C} \text { within } 2 \text { days; } \\
-70^{\circ} \mathrm{C} \text { for more than } 2 \text { days. }\end{array}$ & $\begin{array}{l}\text { Collect on presentation. Sam- } \\
\text { pling repeated for monitoring. }\end{array}$ \\
\hline $\begin{array}{l}\text { Lower respiratory tract } \\
\text { Sputum } \\
\text { Endotracheal aspirate } \\
\text { Bronchoalveolar lavage }\end{array}$ & Sterile container. & $\begin{array}{l}2-8^{\circ} \mathrm{C} \text { within } 2 \text { days; } \\
-70^{\circ} \mathrm{C} \text { for more than } 2 \text { days. }\end{array}$ & $\begin{array}{l}\text { Collect on presentation. Sam- } \\
\text { pling repeated for monitoring. }\end{array}$ \\
\hline Lung tissue from biopsy/ autopsy & $\begin{array}{l}\text { Sterile container with saline or } \\
\text { VTM }^{*} \text {. }\end{array}$ & $\begin{array}{l}2-8^{\circ} \mathrm{C} \text { within } 24 \text { hours; } \\
-70^{\circ} \mathrm{C} \text { for more than } 24 \text { hours. }\end{array}$ & \\
\hline Serum & $\begin{array}{l}\text { Serum separator tubes } \\
\text { (collect 3-5 ml whole blood). }\end{array}$ & $\begin{array}{l}2-8^{\circ} \mathrm{C} \text { within } 5 \text { days; } \\
-70^{\circ} \mathrm{C} \text { for more than } 5 \text { days. }\end{array}$ & $\begin{array}{l}\text { Paired samples, initially in the } \\
\text { first week of illness or contact } \\
\text { and then 2-4 weeks later. }\end{array}$ \\
\hline Whole blood & Collection tube. & $\begin{array}{l}2-8^{\circ} \mathrm{C} \text { within } 5 \text { days; } \\
-70^{\circ} \mathrm{C} \text { for more than } 5 \text { days. }\end{array}$ & $\begin{array}{l}\text { Collect on presentation. Sam- } \\
\text { pling repeated for monitoring. }\end{array}$ \\
\hline Stool & Stool container. & $\begin{array}{l}2-8^{\circ} \mathrm{C} \text { within } 5 \text { days; } \\
-70^{\circ} \mathrm{C} \text { for more than } 5 \text { days. }\end{array}$ & $\begin{array}{l}\text { Collect on presentation. Sam- } \\
\text { pling repeated for monitoring. }\end{array}$ \\
\hline Urine & Urine container. & $\begin{array}{l}2-8^{\circ} \mathrm{C} \text { within } 5 \text { days; } \\
-70^{\circ} \mathrm{C} \text { for more than } 5 \text { days. }\end{array}$ & $\begin{array}{l}\text { Collect on presentation. Sam- } \\
\text { pling repeated for monitoring. }\end{array}$ \\
\hline
\end{tabular}

*VTM is the viral transport medium containing antifungal and antibiotic supplements. If VTM is unavailable, sterile saline may be used. 
Table 3. Testing priorities for the diagnosis of SARS-CoV-2 infection (ESC Guidance, 2020)

\begin{tabular}{|c|c|c|}
\hline Priority & Cases & Remarks \\
\hline I & $\begin{array}{l}\text { Hospitalized patients. } \\
\text { Symptomatic healthcare workers. }\end{array}$ & $\begin{array}{l}\text { Hospitalized patients to be provided with optimal care. } \\
\text { Risk of nosocomial infections to be reduced. } \\
\text { Integrity of healthcare system to be maintained. }\end{array}$ \\
\hline II & $\begin{array}{l}\text { Symptomatic patients in long-term care facilities. } \\
\text { Symptomatic patients of } 65 \text { years age and older. } \\
\text { Symptomatic patients with underlying health conditions. } \\
\text { Symptomatic first responders. }\end{array}$ & $\begin{array}{l}\text { Patients at higher risk of complications to be promptly } \\
\text { identified. }\end{array}$ \\
\hline III & $\begin{array}{l}\text { Symptomatic infrastructure workers. } \\
\text { Symptomatic individuals who are not in categories of I and II priority. } \\
\text { Health care workers and first responders. } \\
\text { Individuals with mild symptoms. }\end{array}$ & $\begin{array}{l}\text { Testing the community with rapidly increasing hospi- } \\
\text { tal cases (as per the available resources). } \\
\text { Ensuring the health of essential workers. }\end{array}$ \\
\hline IV & Individuals without symptoms. & Non-priority. \\
\hline
\end{tabular}

\section{Auxiliary diagnostic tests}

The clinical signs in patients infected with SARS-CoV-2 are highly atypical. Therefore, auxiliary examinations are necessary for the diagnosis of COVID-19, keeping in mind the epidemiological history as well. The testing capacity may not be sufficient for widespread testing, such as drivethrough testing in South Korea. Thus, suspected cases can be categorized priority-wise (Table 3).

\section{Molecular or nucleic acid-based techniques}

The two types of nucleic acid-based techniques that are being used for the detection of SARS-CoV-2 are rRTPCR and high-throughput sequencing. The isolation and culture of viruses from blood followed by highthroughput sequencing is the highly specific method for identification of SARS-CoV-2 (Zhou et al., 2020), a part from electron microscopy. But this method has limited clinical application because of equipment requirements and cost involved. So, rRT-PCR is considered effective as well as a reliable method to detect such pathogenic viruses in blood and respiratory secretions (Corman et al., 2020). Although it is advisable to perform viral sequencing of a percentage of samples from the clinical cases to monitor the genetic mutations in virus (WHO, 2020b).

The rRT-PCR assays are the most widely used in vitro diagnostic tests, which are being used for the confirmatory diagnosis of SARS-CoV-2 throughout the globe. In certain RT-PCR protocols, two genes are being examined using a two-step interpretation algorithm (Chu et al., 2020; National Institute for Viral Disease Control and Prevention, 2020) with the identification of one gene as a screening test and of the second gene for a confirmatory test. One such novel and the highly specific assay was developed by the Tib-Molbiol, Germany, targeting the envelope (E) gene for screening and RNA-dependent RNA polymerase (RdRp) gene for the confirmation (Corman et al., 2020).
Similarly, a first-line screening assay that uses the TaqMan fluorogenic probe and is based on the E gene has been designed by the Indian Council of Medical Research (ICMR, 2020b). Out of a total of 106 Virus, Research and Diagnostic Laboratories (VRDLs) established under the Department of Health Research/ICMR, 13 operational and 18 new VRDLs are carrying out this E gene-based screening and it is eventually proposed to involve the rest of the VRDLs in SARS-CoV-2 testing (Gupta et al., 2020). The positive samples are immediately sent in triple packaging to the reference laboratory i.e. ICMR- National Institute of Virology (ICMR-NIV), Pune for confirmatory assays based on the ORF 1b, RdRp gene, E gene and N gene(ICMR, 2020b).

In certain protocols, three or more genes are examined and the test is considered positive only when all genes are detected for e.g., an emergency test targeting the N1, N2, N3 and RP genes has been approved by the FDA for the diagnosis of SARS-CoV-2. The presence of only one or two genes is interpreted as indeterminate. Another example is the Xpert ${ }^{\circledR}$ Xpress SARS-CoV-2 test developed by the Cepheid. This emergency test approved by the FDA and ICMR targets the N2 and E genes. The presence of both the genes as well as the N2 gene alone is considered positive, whereas if only E gene is present, it is interpreted as presumptive positive (Gupta et al., 2019). With a turnaround time of just $45 \mathrm{~min}$, it can be referred to as a frontline point-of-care test for the diagnosis of SARS-CoV-2 in the nasopharyngeal swabs, nasal wash and aspirate from the suspected individual (Cepheid, 2020; Vashisht, 2020).

Various other assays including Roche COBAS-6800/ 8800 targeting E and RdRp gene; TaqPath ABI targeting S, $\mathrm{N}$ and orf- 1 ab genes; and Truenat (make-in-India product for screening) are also available. Many commercial diagnostic kits have also been validated by the ICMR-NIV such as Altona diagnostics based on the $E$ and S genes; KILPEST based on the E, RdRp and N genes; MY LAB Patho detect kit (make-in-India product); SD Biosensor kits based on the 
E and RdRp ORF 1 ab genes; and Seegene based on the E, RdRp and N genes (Gupta et al., 2019). The IIT, New Delhi has also designed a probe-free kit aimed at easier and cheaper diagnosis with lesser turnaround time (Gupta et al., 2020b; Vashisht, 2020).

Due to the worldwide efforts of the research community, prominent advances are being made for the prompt diagnosis of SARS-CoV-2. One such development is the Vivalytic COVID-19 test by Bosch, Germany, which is a rapid point-of-care molecular test that can simultaneously detect SARS-CoV-2 along with nine other respiratory viruses, including influenza A and B (Vashisht, 2020). Another benchmark is the development of the Abbott ID Now ${ }^{\mathrm{TM}}$ COVID-19 test, which detects SARS-CoV-2 from the nasal, nasopharyngeal, throat and oropharyngeal swabs in as little as five minutes (ID NOW, 2020; Vashisht, 2020). This test based on the isothermal nucleic acid amplification targeting the RdRp gene, has received FDA Emergency Use Authorization(EUA). It utilizes a portable touchscreen-operated instrument, i.e., ID Now and can be used in locations such as hospitals, offices and hotspots of the outbreak (Vashisht, 2020).

Although these nucleic acid-based assays have good sensitivity but the negative results cannot always rule out the possibility of SARS-CoV-2 infection. Such falsenegative results can arise due to various factors such as inadequate poor quality of the sample, late or very early sampling, improper transportation of sample and technical errors in the test.

\section{Immunoassays}

Several serological tests have been developed for the diagnosis of infection caused by SARS-CoV-2; most of which are based on the IgM and IgG. IgM antibodies can be detected in the serum at 10 to 30 days after SARS-CoV-2 infection and then diminishes, while IgG can be detected after 20 days and persists for a long time after the infection (Tan et al., 2020c). The ICMR has also licensed antibodybased blood tests for the rapid diagnosis of SARS-CoV-2 infection with the advisory to retest after 10 days or confirm by rRT-PCR in case of negative results (ICMR, 2020a).

Various formats of diagnostic immunoassays are being developed, such as lateral flow immunoassay (LFIA) based COVID-19 test developed by BioMedomics, USA which detects the IgM and IgG antibodies in the suspected individuals in around ten minutes (Vashisht, 2020). This test is rapid and easy to perform in field conditions using just $20 \mu \mathrm{l}$ of blood (finger-pricked) or $10 \mu \mathrm{l}$ of serum. Similarly, the test named SARS-CoV-2 rapid developed by Pharmacyt AG, Germany gives the results in 20 minutes from just two drops of the blood pricked from the finger (Vashisht, 2020). Another LFIA based assay by Chembio Diagnostics, USA i.e. DPP COVID-19 IgM/IgG test has received FDA EUA. The results are obtained in 15 minutes using the blood pricked from finger and the optical readings are provided in $\mathrm{Mi}$ croReader 1 and 2 analyzers instead of visual detection (Vashisht, 2020). A large number of rapid IgM/IgG tests have been developed by several IVD companies, such as Beijing Lepu Medical Technology, Biomerica, Guangzhou Wondfo Biotech, Jiangsu Medomics Medical Technologies, Innovita Biological Technology, Sona Nanotech, Sugentech, Sure Bio-Tech Xiamen AmonMed Biotechnology and Zhenjiang Orient Gene Biotech (Vashisht, 2020). However, these rapid tests need to be assessed strictly for their clinical accuracy before providing authorization. There have been reports from various European countries suggesting that the analytical performance of most of the rapid test kits procured from China was not good and they did not work in over $70 \%$ of SARS-CoV-2 cases (Vashisht, 2020).

The main drawback of IgM and IgG based tests is that they are detectable after two weeks of the onset of infection. Thus more assays involving other biomarkers need to be developed for the rapid diagnosis of SARS-CoV-2 infection in early stages. The automated chemiluminescence immunoassay (CLIA) are advantageous over LFIA tests because of the analysis of very high throughput of samples and the ability to incorporate many clinical tests based on other biomarkers, such as C-reactive protein (CRP). Examples of CLIA based tests include the DZ-Lite SARS-CoV-2 CLIA IgM and IgG tests by Diazyme, USA that have received FDA EUA and have a throughput of 50 tests per hour (Vashisht, 2020).

Commercial enzyme-linked immunosorbent assay (ELISA) kits based on the IgM and IgG antibodies have also been developed by the manufacturers, such as DRG Diagnostics GmbH, Epitope Diagnostics, Euroimmun and IBL International (Vashisht, 2020).

Although the serological tests have the limitation of cross-reactivity to other coronaviruses (Meyer et al., 2020), the validated tests conducted on paired serum samples (acute and convalescent-phase) can aid in retrospective assessment of the ongoing outbreak of SARS-CoV-2.

\section{Antigen based detection}

These tests detect the protein fragments of the virus by testing from the nasal swabs. Many antigen-based commercial kits are being developed for the purpose of surveillance (Administrator, 2020). The test is rapid as compared to rRT-PCR but despite being highly specific for the SARS-CoV-2, the sensitivity is lower; therefore, the negative results should be preceded by rRT-PCR for confirmation (US Food and Drug Administration, 2020).

\section{Radiological techniques}

Considering certain false negative results of rRT-PCR, it needs to be complemented with other detection methods 
such as radiology as well. The chest $\mathrm{x}$-ray is recommended in all the patients with suspected pneumonia and reveals unilateral lung infiltrates in $25 \%$, and bilateral lung infiltrates in 75\% cases (Song et al., 2020; Huang et al., 2020a; Chen et al., 2020b).

Computed tomography (CT) scans are considered as the primary imaging module in some of the countries, such as China. Although the CT scans are not confirmatory for the diagnosis of SARS-CoV-2 infection, they may be helpful in the management of individual cases and detecting the complications (Beeching et al., 2020). Especially the high-resolution CT (HRCT) for the chest is essential for early diagnosis and evaluation of disease severity of patients with SARS-CoV-2 (Pan et al., 2020). In a cohort study involving more than 1000 patients in a hyperendemic area in China, the sensitivity of chest CT was found to be higher (88\%) as compared to initial rRTPCR (59\%) (Ai et al., 2020).

But, it should be emphasized that an individual with SARS-CoV-2 infection can have a normal chest CT. Conversely, the abnormal chest CT is also non-specific as the findings are indistinguishable from viral pneumonia of different aetiologies, and this is a major shortcoming of this technique. The typical features which have been found in the lungs of patients infected with SARS-CoV-2 include the ground-glass opacity or consolidation at multiple sites in the bilateral lobular and subsegmental areas (at the periphery or posterior aspect especially in the lower lobes (Huang et al., 2020a; Salehi et al., 2020; Xu et al., 2020); apart from air bronchograms, crazy-paving pattern and reverse halo/perilobular pattern (British Society of Thoracic Imaging, 2020). The atypical features of the disease which are generally found in the later stages include smooth or irregular thickening of the interlobular area or septa, adjacent pleura and involvement of the subpleura as well; and rarely bronchiectasis, cavitation, pneumothorax, pleural and pericardial effusion and lymphadenopathy (Huang et al., 2020a; Salehi et al., 2020; Xu et al., 2020).

\section{Lung ultrasound}

Lung ultrasound technique can aid in the diagnosis of SARS-CoV-2 infection since it is highly sensitive for the detection of abnormalities such as ground-glass opacity, pleural thickening and subpleural consolidation; besides having the advantage of portability and reproducibility (Beeching et al., 2020). It can be used in pregnant women and children as well (Denina et al., 2020; Inchingolo et al., 2020). The typical features observed in lung ultrasound of patients infected with SARS-CoV-2 include air bronchograms, B-lines, white lung, pleural line thickening and consolidations (Soldati et al., 2020; Moro et al., 2020; Cheung et al., 2020a; Moore and Gardiner, 2020).

\section{Other diagnostic assays}

Reverse transcription loop-mediated isothermal amplification (RT-LAMP) assay is a prospective test for the detection of the RNA of SARS-CoV-2. The technique is simple, quick and the viral DNA produced is more in quantity as compared to rRT-PCR (Beeching et al., 2020). The RT-LAMP based assays are currently being developed and evaluated (Baek et al., 2020; Lu et al., 2020; Park et al., 2020). Other such emerging formats which are being researched include the CRISPR technology (Sheridan, 2020), lab-on-a-chip and microfluidics (Vashisht, 2020).

\section{Future perspective of smart diagnostics}

In the present-day era of information and technology, smartphones equipped with the global positioning system (GPS) and internet are omnipresent, which can be efficiently exploited as the analysis and surveillance platform. Examples of such smart fitness devices that have already been anticipated in other diseases include the fitbit wearable device for influenza-like illness (Cecile and Mauricio, 2020; Radin et al., 2020) and iHealth Align device for blood glucose monitoring (iHealth Align, 2020). In a remarkable move, the Aarogya Setu mobile App has been launched in India on $2^{\text {nd }}$ April 2020, which enables bluetooth based contact tracing and mapping of likely hotspots apart from disseminating the relevant information about SARS-CoV-2 (Aarogya Setu, 2020). Furthermore, there is a need for the development of an automated smartphone-based POC device equipped with the molecular and immunological tests based on the SARS-CoV-2 biomarkers so that the diagnosis as well as reporting of this highly communicable disease can transform to software-based analytics.

\section{Conclusion}

The SARS-CoV-2 has become a global pandemic defying the geographical borders and putting the lives of billions at risk, especially those at the extreme of ages and immunocompromised. Diagnosis of the SARS-CoV-2 infection currently relies on a combination of epidemiological criteria, evident clinical manifestations and in vitro diagnostic assays. Although there have been commendable advances in the diagnostic assays but, considering the sensitivity and specificity based disadvantages in the presently available diagnostics, it becomes imperative to highlight that the nations need to invest more in the research and smart integrated diagnostics so that safe, rapid and reliable technologies for the detection of SARS-CoV-2 can be developed and implemented in large scale for the accurate diagnosis and containment of this outbreak. 


\section{References}

Aarogya Setu (2020): Aarogya Setu is now open source. Press Release. Available from: https://static.mygov.in/rest/ s3fs-public/mygov_159050700051307401.pdf [Last accessed on 2020 June 04].

Administrator J Website (2020): Global progress on COVID-19 serology-based testing. Johns Hopkins Center for Health Security. Available from: http://www.centerforhealthsecurity.org/resources/ COVID-19/Serologybased-tests-for-COVID-19.html. [Last accessed on 2020 June 04].

Ai T, Yang Z, Hou H, Zhan C, Chen C, Lv W, Tao Q, Sun Z, Xia L (2020): Correlation of chest CT and RT-PCR testing in coronavirus disease 2019 (COVID-19) in China: A report of 1014 cases. Radiol. 26, 200642. https://doi. org/10.1148/radiol.2020200642

Arentz M, Yim E, Klaff L, Lokhandwala S, Riedo FX, Chong M, Lee M (2020): Characteristics and outcomes of 21 critically ill patients with COVID-19 in Washington State. JAMA 323(16),1612-1614. https://doi.org/10.1001/ jama.2020.4326

Baek YH, Um J, Antigua KJC, Parka JH, Kimc Y, Oh S, Kim Y, Choi WS, Kim SG, Jeong JH, Chin BS, Nicolas HDG, Ahn JY, Shin KS, Choi YK, Park S, Song MS (2020): Development of a reverse transcription-loop-mediated isothermal amplification as a rapid early-detection method for novel SARS-CoV-2. Emerg. Microbes. Infect. 9(1), 9981107. https://doi.org/10.1080/22221751.2020.1756698

Beeching NJ, Fletcher, TE, Fowler R (2020): BMJ best practice. Coronovirus disease 2019 (COVID-19). Available from http://bestpractice.bmj.com/topics/en-gb/3000168. [Last accessed on 2020 June 04].

British Society of Thoracic Imaging (2020): Thoracic imaging in COVID-19 infection: Guidance for the reporting radiologist-version 2. 2020 [Last accessed on 2020 June 04].

Cao J, Tu WJ, Cheng W, Yu L, Liu Ya-Kun, Hu X, Liu Q (2020): Clinical features and short-term outcomes of 102 patients with corona virus disease 2019 in Wuhan, China. Clin. Infect. Dis. 71(15), 748-755. https://doi.org/10.1093/cid/ ciaa243

Casas CG, Català A, Hernández GC, Jimenez PR, Nieto DF, Lario ARV, Fernandez IN, Villaverde RR, Lopez DF, Velasco ML, Gavin JG, Baniandres O, Cruz CG, Lahuerta VM, Cubiro X, Nart IF, Enriquez GS, Romani J, Novell XF, Olivera AM, Riesco MR, Blasco PB, Ortigosa JS, Rodriguez M, Dovel IG (2020): Classification of the cutaneous manifestations of COVID-19: A rapid prospective nationwide consensus study in Spain with 375 cases. Br. J. Dermatol. 183, 3-4. https://doi. org/10.1111/bjd.19163

Cascella M, Rajnik M, Cuomo A, Dulebohn SC, Di Napoli R (2020): Features, evaluation and treatment coronavirus (COVID-19). In StatPearls. Treasure Island (FL): StatPearls Publishing. Available from: https://www. ncbi.nlm.nih.gov/books/NBK554776/ [Last accessed on 2020 June 04 ].
Cecile V, Mauricio S (2020): Fitbitinformed influenza forecasts. The Lancet Digital Health. 2, 54-55. https://doi. org/10.1016/S2589-7500(19)30241-9

Centers for Disease Control and Prevention (2020): Interim guidelines for collecting, handling, and testing clinical specimens from persons for coronavirus disease 2019 (COVID-19). https://www.cdc.gov/coronavirus/2019$\mathrm{nCoV} /$ lab/guidelines-clinical-specimens.html (Updated on March 21, 2020).

Cepheid (2020): Cepheid announces development of test for new coronavirus strain (2019-nCoV). Available from: https://www.prnewswire.com/news-releases/cepheid announces-developmentof-test-for-new-coronavirusstrain-2019-ncov 301001684.html. [Last accessed on 2020 June 02].

Chan JF, Yuan S, Kok KH, To KKW, Chu H, Yang J, Xing F, Liu J, Yip CCY, Poon RWS, Tsoi HW, Lo SKF, Chan KH, Poon VKM, Chan WM, Daniel J, Cai JP, Cheng VCC, Chen H, Hiu CKM, Yuen KY (2020): A familial cluster of pneumonia associated with the 2019 novel coronavirus indicating person-to-person transmission: A study of a family cluster. Lancet 395, 514-523. https://doi.org/10.1016/ S0140-6736(20)30154-9

Chen N, Zhou M, Dong X, Qu J, Gong F, Han Y, Qui Y, Wang J, Liu Y, Wei Y, Xia J, Yu T, Zhang X, Zhang L (2020a): Epidemiological and clinical characteristics of 99 cases of 2019 novel coronavirus pneumonia in Wuhan, China: A descriptive study. Lancet 395(10223), 507-513. https://doi.org/10.1016/S0140-6736(20)30211-7

Chen T, Wu D, Chen H, Yan W, Yang D, Chen G, Ma K, Xu D, Yu H, Wang H, Wang T, Gao W, Chen J, Ding C, Zhang X, Hunag J, Ham M, Li S, Luo X, Zhao J, Ning Q (2020b): Clinical characteristics of 113 deceased patients with coronavirus disease 2019: Retrospective study. BMJ 368, m1091. https://doi.org/10.1136/bmj.m1091

Cheung JC, Lam KN (2020a): POCUS in COVID-19: Pearls and pitfalls. Lancet Respir. Med. (5), e27. https://doi. org/10.1016/S2213-2600(20)30120-X

Cheung KS, Hung IF, Chan PPY, Lung KC, Tso E, Liu R, Ng YY, Chu MY, Chung TWH, Tam AR, Yip CCY, Leung KH, Fung AYF, Zhang RR, Lin Y, Chen HM, Zhang AJX, To KKW, Chan KH, Yuen KY, Leung WK (2020b): Gastrointestinal manifestations of SARS-CoV-2 infection and virus load in fecal samples from the Hong Kong cohort and systematic review and meta-analysis. Gastroenterol.59(1), 81-95. https://doi.org/10.1053/i.gastro.2020.03.065

Chu DKW, Pan Y, Cheng SMS, Hui KPY, Krishnan P, Liu Y, Ng DYM, Wan CKC, Yang P, Wang Q, Peiris M, Poon LLM (2020): Molecular diagnosis of a novel coronavirus (2019-nCoV) causing an outbreak of pneumonia. Clin. Chem. 66(4), 549-555. https://doi.org/10.1093/ clinchem/hvaa029

Colavita F, Lapa D, Carletti F, Lalle E, Bordi L, Marsella P, Nicastri E, Bevilacqua N, Giancola ML, Corpolongo A, Ippolito G, Capobianchi MR, Castilletti C (2020): SARS-CoV-2 isolation from ocular secretions of patient with COVID-19 in Italy with prolonged viral RNA detection. Ann. Intern. Med. M20-1176. https://doi.org/10.7326/M20-1176 
Corman VM, Landt O, Kaiser M, Molenkamp R, Meijer A, Chu DKW, Bleicker T, Brunink S, Schneider J, Schmidt ML, Mulders DGJC, Hangmans BL, Veer BV, Brink S, Wijsman L, Goderski G, Romette JL, Ellis J, Zamdon M, Peiris M, Goossens H, Reusken C, Koopmans M, Drosten C (2020): Detection of 2019 novel coronavirus (2019-nCoV) by real-time RT-PCR. Euro. Surveill. 25(3), 2000045. https://doi.org/10.2807/1560-7917. ES.2020.25.3.2000045

COVID-19 Coronavirus Pandemic: COVID-19 virus outbreak in worldwide. Available from: https://www.worldometers.info/coronavirus/ [Last accessed on 2020 June 04].

Denina M, Scolfaro C, Silvestro E, Pruccoli G, Mignone F, Zoppo M, Ramenghi U, Garazzino S (2020): Lung ultrasound in children with COVID-19. Pediatrics 146(1), e20201157. https://doi.org/10.1542/peds.2020-1157

Di Micco PD, Russo V, Carannante N, Imparato M, Rodolfi S, Cardillo G, Lodigiani C (2020): Clotting factors in COVID-19: Epidemiological association and prognostic values in different clinical presentations in an Italian cohort. J. Clin. Med. 9(5), 1371. https://doi.org/10.3390/ jem9051371

Druce J, Garcia K, Tran T, Papadakis G, Birch C (2011): Evaluation of swabs, transport media, and specimen transport conditions for optimal detection of viruses by PCR. J. Clin. Microbiol. 50(3), 1064-1065. https://doi. org/10.1128/JCM.06551-11

ESC (2020): ESC Guidance for the diagnosis and management of CV disease during the COVID-19 pandemic. Last updated on 21 April 2020. @The European Society of Cardiology. All rights reserved. [Last accessed on 2020 June 04].

Galván CC, Catalá A, Carretero Hernandéz G, Rodríguez-Jiménez D, Llamas-Nieto D, Rodríguez-Villa Lario A, Navarro Fernández I, Ruiz-Villaverde R, Falkenhain-López D, Llamas Velasco M, García-Gavín J, Baniandrés O, Gonzáles-Cruz C, Morrilas-Lahuerta V, Cubiró X, Figueras Nart I, Selda-Enriquez G, Romaní J, Fustá-Novell X, Melian-Olivera A, Roncero Riesco M, Burgos-Blasco P, Sola Ortigosa J, Feito Rodriguez M, García-Doval I (2020): Classification of the cutaneous manifestation of COVID-19: a rapid prospective nationwide consensus study in Spain with 375 cases. Br. J. Dermatol.183,71-77.https://doi.org/10.1111/bjd.19163

Garazzino S, Montagnani C, Donà D, Meini A, Felici E, Vergine G, Bernardi S, Giacchero R, Vecchio Al, Marchisio P, Nicolini G, Pierantoni L, Rabbone I, Banderali G, Denina M, Venturini E, Krzysztofiak A, Badolato R, Bianchini S, Gaali L, Villani A, Gattinara GC (2020): Multicentre Italian study of SARS-CoV-2 infection in children and adolescents, preliminary data as at 10 April 2020. Euro. Surveill.25(18), pii=2000600. https:// doi.org/10.2807/1560-7917.ES.2020.25.18.2000600

Giacomelli A, Pezzati L, Conti F, Bernacchia D, Siano M, Oreni L, Rusconi S, Gervasoni C, Ridolfo, AL, Rizzardini G, Antinori S, Galli M (2020): Self-reported olfactory and taste disorders in SARS-CoV-2 patients: a cross-sectional study. Clin. Infec. Dis. 24(7), 3440-3441. https://doi. org/10.26355/eurrev_202004_20797.

Goyal P, Choi JJ, Pinheiro LC, Schenck EJ, Chen R, Jabri A, Satlin MJ, Campion TR, Nahid M, Ringel JB, Hoffman KL, Alshak MN, Li HA, Wehmeyer GT, Rajan M, Reshetnyak E, Hupert N, Horn EM, Martinez FJ, Gulick RM, Safford MM (2020): Clinical characteristics of Covid-19 in New York City. N. Engl. J. Med. 382, 2372-2374. https://doi. org/10.1056/NEJMc2010419

Guan WJ, Ni ZY, Hu Y, Liang WH, Ou CQ, He JX, Liu L, Shan H, Lei CL, Hui DSC, Du B, Li LJ, Zeng G, Yuen KY, Chen RC, Tang CL, Wang T, Chen PY, Xiang J, Li SY, Wang JL, Liang ZJ, Peng YX, Wei L, Liu Y, Hu YH, Peng P, Wang JM, Liu JY, Chen Z, Li G, Zheng ZJ, Qiu SQ, Luo J, Ye CJ, Zhu SY, Zhong NS (2020): Clinical characteristics of coronavirus disease 2019 in China. N. Engl. J. Med. 382(18), 1708-1720. https://doi.org/10.1056/NEJMoa2002032

Gudbjartsson DF, Helgason A, Jonsson H, Magnusson OT, Melsted P, Norddahl GL, Saemundsdottir, J, Sigurdsson A, Sulem P, Agustsdottir AB, Eiriksdottir B, Fridriksdottir R, Gardarsdottir EE, Georgsson G, Gretarsdottir OS, Gudmundsson KR, Gunnarsdottir TR, Gylfason A, Holm H, Jensson BO, Jonasdottir A, Jonsson F, Josefsdottir KS, Kristjansson T, Magnusdottir DN, Roux L, Sigmundsdottir G, Sveinbjornsson G, Sveinsdottir KE, Sveinsdottir M, Thorarensen EA, Thorbjornsson B, Löve A, Masson G, Jonsdottir I, Möller, AD, Gudnason T, Kristinsson KG, Thorsteinsdottir U, Stefansson K (2020): Spread of SARS-CoV-2 in the Icelandic population. N. Engl. J. Med. 382(24), 2302-2315. https://doi. org/10.1056/NEJMoa2006100

Gupta AK, Jneid H, Addison D, Ardehali H, Boehme AK, Borgaonkar S, Boulestreau R, Clerkin K, Delarche N, deVon HA, Grumbach IM, Gutierrez J, Jones DA, Kapil V, Maniero C, Mentias A, Miller PS, Ng SM, Parekh JD, Sanchez RH, Sawicki KT, Riele ASJM, Remme CA, London B (2020a): Current perspectives on coronavirus 2019 (COVID-19) and cardiovascular disease: A white paper by the JAHA editors. J. Am. Heart Assoc. 9(12), e017013. https://doi.org/10.1161/JAHA.120.017013

Gupta N, Potdar V, Praharaj I, Giri S, Sapkal G, Yadav P (2020b): Laboratory preparedness for SARS-CoV-2 testing in India: Harnessing a network of virus research \& diagnostic laboratories. Ind. J. Med. Res. 151, 216-225. https://doi.org/10.4103/ijmr.IJMR 594 20

Gupta P, Goyal K, Kanta P, Ghosh A, Singh MP (2019): Novel 2019-coronavirus on new year's Eve. Ind. J. Med. Microbiol. 37, 459-477. https://doi.org/10.4103/ijmm. IJMM_20_54

Hong KH, Lee SW, Kim TS, Huh HJ, Lee J, Kim SY, Park JS (2020): Guidelines for laboratory diagnosis of coronavirus disease 2019 (COVID-19) in Korea. Ann. Lab. Med. 40, 351-360. https://doi.org/10.3343/alm.2020.40.5.351

Huang C, Wang Y, Li X, Ren L, Zhao J, Hu Y, Zhang L, Fan G, Xu J, Gu X, Cheng Z, Yu T, Xia J, Wei Y, Wu W, Xie X, Yin W, Li H, Liu M, Xiao Y, Gao H, Guo L, Xie J, Wang G, Jiang R, Gao Z, Jin Q, Wang J, Cao B (2020a): Clinical features of patients infected with 2019 novel coronavirus in 
Wuhan, China. Lancet 395(10223), 497-506. https:// doi.org/10.1016/S0140-6736(20)30183-5

Huang G, Kovalic AJ, Graber CJ (2020b): Prognostic value of leukocytosis and lymphopenia for coronavirus disease severity. Emerg. Infect. Dis. 26(8), 1839-1841. https:// doi.org/10.3201/eid2608.201160

ICMR (2020a): ICMR-Advisory. Advisory to start rapid antibody based blood test for COVID-19 (4 April 2020). Accessed from: https://dddcovid19.in/uploads/advisories/Advisory_Antibody_Testing_04042020.pdf[Last accessed on 2020 June 03].

ICMR (2020b): ICMR- First line screening assay. Standard operating procedure for detection of 2019 novel coronavirus (2019-nCoV) in suspected human cases by rRT-PCR: First line screening assay. Accessed from: https://www.icmr.gov.in/pdf/covid/labs/1_SOP_for_ First_Line_Screening_Assay_for_2019_nCoV.pdf[Last accessed on 2020 June 04]

ID NOW (2020): Covid-19. Available online: https://www.alere. com/en/home/product-details/id-now-covid-19.html [Last accessed on 2020 June 04].

iHealth Align. Available online: https://ihealthlabs.com/glucometer/ihealth-align/ [Last accessed on 2020 June 04].

Inchingolo R, Smargiassi A, Moro F, Buonsenso D, Salvi S, Giacomo PD, Scoppettuolo G, Demi L, Soldati G, Testa AC (2020): The diagnosis of pneumonia in a pregnant woman with COVID-19 using maternal lung ultrasound. Am. J. Obstet. Gynecol. 223(1), 9-11. https://doi. org/10.1016/j.ajog.2020.04.020

Jin X, Lian JS, Hu JH, Gao J, Lin Zheng L, Zhang YM, Hao SR, Jia HY, Cai H, Zhang XL, Yu GD, Xu KJ, Wang XY, Gu JQ, Zhang SY, Ye CY, Jin CL, Lu YF, Yu X, Yu XP, Huang JR, Xu KL, Ni Q, Yu CB, Zhu B, Li YT, Liu J, Zhao H, Zhang X, Yu L, Guo YZ, Su JW, Tao JJ, Lang GJ, Wu XX, Wu WR, Qv TT, Xiang DR, Yi P, Shi D, Chen Y, Ren Y, Qiu YQ, Li LJ, Sheng J, Yang Y (2020): Epidemiological, clinical and virological characteristics of 74 cases of coronavirus-infected disease 2019 (COVID-19) with gastrointestinal symptoms. Gut 69(6), 1002-1009. https://doi.org/10.1136/gutinl-2020-320926

Kimball A, Hatfield KM, Arons M, James A, Taylor J, Spicer K, Bardossy AC, Oakley LP, Tanwar S, Chisty Z, Bell JM, Methner M, Harney J, Jacobs JR, Carlson CM, McLaughlin HP, Stone N, Clark S, Brostrom-Smith C, Page LC, Kay M, Lewis J, Russell D, Hiatt B, Gant J, Duchin JS, Clark TA, Honein MA, Reddy SC, Jernigan JA (2020): Asymptomatic and presymptomatic SARSCoV-2 infections in residents of a long-term care skilled nursing facility-King County, Washington, March 2020. Morb. Mortal. Wkly. Rep. 69 (13),377-381. https:// doi.org/10.15585/mmwr.mm6913e1

Korea Centers of Disease Control and Prevention (2020): Guidelines in response to coronavirus disease 2019. 7-3rd ed. (for local government). Available from: https:// www.cdc.go.kr/board/board.es?mid=a20507020000\& bid $=0019 \&$ act $=$ view\&list_no $=366558 \&$ tag $=\&$ nPage $=1$ (Updated on March 15, 2020). [Last accessed on 2020 June 04].
Lagunas-Rangel FA (2020): Neutrophil-to-lymphocyte ratio and lymphocyte-to-C-reactive protein ratio in patients with severe coronavirus disease 2019 (COVID-19): A meta-analysis. J. Med. Virol. 1-2. https://doi. org/10.1002/jmv.25819

Lauer SA, Grantz KH, Bi Q, Forrest K Jones FK, Qulu Zheng Q, Hannah R Meredith HR, Andrew S Azman AS, Nicholas G Reich NG, Justin Lessler J (2020): The incubation period of coronavirus disease 2019 (COVID-19) from publicly reported confirmed cases: Estimation and application. Ann. Intern. Med. 172(9), 577-582. https:// doi.org/10.7326/M20-0504

Lechien JR, Chiesa-Estomba CM, De Siati DR, Horoi M, Bon SD, Rodriguez A, Dequanter D, Blecic S, Afia FE, Distinguin L, Chekkoury-Idrissi Y, Hans S, Delgado IL, Henriquez CC, Lavigne P, Falanga C, Barillari MR, Cammaroto G, Khalife M, Pierre Leich, Christel Souchay, Camelia Rossi, Journe F, Hsieh J, Edjlali M, Carlier R, Ris L, Lovato A, Filippis CDC, Coppee F, Fakhry N, Ayad T, Saussez, S (2020): Olfactory and gustatory dysfunctions as a clinical presentation of mild-to-moderate forms of the coronavirus disease (COVID-19): A multicenter European study. Eur. Arch. Otorhinolaryngol. 277, 2251-2261. https://doi.org/10.1007/s00405-020-05965-1

Li Q, Guan X, Wu P, Wang X, Zhou L, Tong Y, Ren R, Leung KSM, Lau EHY, Wong JY, Xing X, Xiang N, Wu Y, Li C, Chen Q, Li D, Liu T, Zhai j, Liu M, Tu W, Chen C, Jin L, Yang R, Wang Q, Zhao S, Wang R, Liu H, Luo Y, Liu Y, Shao G, Li H, Tao Z, Yang Y, Deng Z, Liu B, Ma Z, Zhang Y, Shi G, Lam TTY, Wu JT, Gao GF, Cowling BJ, Yang B, Leung GM, Feng Z (2020a): Early transmission dynamics in Wuhan, China, of novel coronavirus-infected pneumonia. N. Engl. J. Med. 382(13), 1199-1207. https://doi. org/10.1056/NEJMoa2001316

Li LQ, Huang T, Wang YQ, Wang ZP, Liang Y, Huang TB, Zhang HY, Sun W, Wang Y (2020b): COVID-19 patients' clinical characteristics, discharge rate and fatality rate of meta-analysis. J. Med. Virol.92(6), 577-583. https://doi. org/10.1002/jmv.25757

Li X, Geng M, Peng Y, Meng L, Lu S (2020): Molecular immune pathogenesis and diagnosis of COVID-19. J. Pharm. Anal. 10, 102-108. https://doi.org/10.1016/j. jpha.2020.03.001

Liu Y, Du X, Chen J, Jin Y, Peng L, Wang HHX, Luo M, Chen L, Zhao Y (2020a): Neutrophil-to-lymphocyte ratio as an independent risk factor for mortality in hospitalized patients with COVID-19. J. Infect. 81(1), e6-e12. https:// doi.org/10.1016/j.jinf.2020.04.002

Liu YC, Liao CH, Chang CF, Chao CC, Lin YR (2020b): A locally transmitted case of SARS-CoV-2 infection in Taiwan. $\mathrm{N}$. Engl.J. Med.382(11),1070-1072. https://doi.org/10.1056/ NEJMc2001573

Lu R, Wu X, Wan Z, Li Y, Jin X, Zhang C (2020): A novel reverse transcription loop-mediated isothermal amplification method for rapid detection of SARS-CoV-2. Int. J. Mol. Sci. 21(8), 2826. https://doi.org/10.3390/ijms21082826

Manalo IF, Smith MK, Cheeley J, Jacobs R (2020): A dermatologic manifestation of COVID-19: Transient livedo 
reticularis. J. Am. Acad. Dermatol. 83(2), 700. https:// doi.org/10.1016/j.jaad.2020.04.018

Matics TJ, Sanchez-Pinto LN (2017): Adaptation and validation of a pediatric sequential organ failure assessment score and evaluation of the sepsis-3 definitions in critically ill children. JAMA Pediatr. 171(10), el72352. https://doi.org/10.1001/jamapediatrics.2017.2352

McIntosh K (2020): Coronavirus disease 2019 (COVID-19): Epidemiology, virology, clinical features, diagnosis, and prevention.https://doi.org/10.1007/s00705-018-3824-8

Mehta P, McAuley DF, Brown M, Sanchez E, Tattersall RS, Mansosn JJ (2020): COVID-19: consider cytokine storm syndromes and immunosuppression. Lancet 395(10229), 1033-1034. https://doi.org/10.1016/S01406736(20)30628-0

Metlay JP, Waterer GW (2020): Treatment of communityacquired pneumonia during the coronavirus disease 2019 (COVID-19) pandemic. Ann. Intern. Med. 173(4), 304-305. https://doi.org/10.7326/M20-2189

Meyer B, Drosten C, Müller MA (2014): Serological assays for emerging coronaviruses: challenges and pitfalls. Virus Res.194, 175-183. https://doi.org/10.1016/j.virusres.2014.03.018

Mizumoto K, Kagaya K, Zarebski A, Chowell G (2020): Estimating the asymptomatic proportion of coronavirus disease 2019 (COVID-19) cases on board the Diamond Princess cruise ship, Yokohama, Japan, 2020. Euro. Surveill. 25(10), 2000180. https://doi.org/10.2807/1560-7917. ES.2020.25.10.2000180

Moore S, Gardiner E (2020): Point of care and intensive care lung ultrasound: A reference guide for practitioners during COVID-19. Radiography 26(4), e297-e302. https://doi. org/10.1016/j.radi.2020.04.005

Moro F, Buonsenso D, Moruzzi MC, Inchingolo R, Smargiassi A, Demi L, Larici AR, Scambia G, Lanzone A, Testa AC (2020): How to perform lung ultrasound in pregnant women with suspected COVID-19 infection. Ultrasound Obstet. Gynecol. 55(5), 593-598. https://doi. org/10.1002/uog.22028

National Institute for Viral Disease Control and Prevention (2020): Specific primers and probes for detection 2019 novel coronavirus. http://ivdc.chinacdc.cn/ kyjz/202001/t20200121_211337.html(Updated on January 21,2020 ).

Pan Y, Guan H, Zhou S, Wang W, Li Q, Zhu T, Hu Q, Xia L (2020): Initial CT findings and temporal changes in patients with the novel coronavirus pneumonia (2019-nCoV): A study of 63 patients in Wuhan, China. Eur. Radiol.30(6), 3306-3309. https://doi.org/10.1007/s00330-020-06731-x

Park GS, Ku K, Baek SH, Kim SJ, Kim SL, Kim BT, Maeng JS (2020): Development of reverse transcription loopmediated isothermal amplification assays targeting severe acute respiratory syndrome coronavirus 2 . J. Mol. Diagn. 221(1), 68-73. https://doi.org/10.1016/j. jviromet.2015.04.017

Patanavanich R, Glantz SA (2020): Smoking is associated with COVID-19 progression: A meta-analysis. Nicotine Tob. Res. 1-4. https://doi.org/10.1093/ntr/ntaa082
Qin C, Zhou L, Hu Z, Zhang S, Yang S, Tao Y, Xie C, Ma K, Shang K, Wang W, Tian DS (2020): Dysregulation of immune response in patients with COVID-19 in Wuhan, China. Clin. Infect. Dis. 71(15), 762-768. https://doi.org/10.1093/ cid/ciaa248

Radin JM, Wineinger NE, Topol EJ, Steinhubl SR (2020): Harnessing wearable device data to improve state-level real-time surveillance of influenza-like illness in the USA: A population-based study. Lancet Digital Health 1, 85-93. https://doi.org/10.1016/S2589-7500(19)30 $\underline{222-5}$

Recalcati S (2020): Cutaneous manifestations in COVID-19: A first perspective. J. Eur. Acad. Dermatol. Venereol. 34(5), e212-e213. https://doi.org/10.1111/idv.16387

Salehi S, Abedi A, Balakrishnan S, Gholamrezanezhad A (2020): Coronavirus disease 2019 (COVID-19): A systematic review of imaging findings in 919 patients. AJR Am. J. Roentgenol. 215(1), 87-93. https://doi.org/10.2214/ AJR.20.23034

Seymour CW, Kennedy JN, Wang S, Chang CCH, Elliott CF, Xu Z, Berry S, Clermont G, Cooper G, Gomez H, Huang DT, Kellum JA, Mi Q, Opal SM, Talisa V, Poll T, Visweswaran S, Vodovotz Y, Weiss JC, Yealy DM, Yende S, Angus DC (2019): Derivation, validation, and potential treatment implications of novel clinical phenotypes for sepsis. JAMA, 321(20), 2003-2017. https://doi.org/10.1001/ jama.2019.5791

Sheridan C (2020): Fast, portable tests come online to curb coronavirus pandemic. Nat. Biotechnol. 38, 515-518. https://doi.org/10.1038/d41587-020-00010-2

Soldati G, Smargiassi A, Inchingolo R, Buonsenso D, Perrone T, Briganti DF, Stefano Perlini S, Torri E, Mariani A, Mossolani EE, Tursi F, Mento F, Demi L (2020): Proposal for international standardization of the use of lung ultrasound for COVID-19 patients; a simple, quantitative, reproducible method. J. Ultrasound Med. 39, 1413-1419. https://doi.org/10.1002/jum.15285

Song F, Shi N, Shan F, Zhang Z, Shen J, Lu H, Ling Y, Jiang Y, Shi Y (2020): Emerging coronavirus 2019-nCoV pneumonia. Radiol. 295(1), 210-217. https://doi.org/10.1148/ radiol.2020200274

Sutton D, Fuchs K, D'Alton M, Goffman D (2020): Universal screening for SARS-CoV-2 in women admitted for delivery. N. Engl. J. Med. 382, 2163-2164. https://doi. org/10.1056/NEJMc2009316

Tan C, Huang Y, Shi F, Tan K, Ma Q, Chen Y, Jiang X, Li X (2020a): C-reactive protein correlates with CT findings and predicts severe COVID-19 early. J. Med. Virol. 92(7), 856-862. https://doi.org/10.1002/jmv.25871

Tan L, Wang Q, Zhang D, Ding J, Huang Q, Tang YQ, Wang Q, Miao $\mathrm{H}$ (2020b): Lymphopenia predicts disease severity of COVID-19: A descriptive and predictive study. Signal Transduct. Target Ther. 5, 33. https://doi.org/10.1038/ s41392-020-0148-4

Tan W, Lu Y, Zhang J, Wang J, Dan Y, Tan Z, He X, Qian C, Sun Q, Hu Q, Liu H, Ye S, Xiang X, Zhou Y, Zhang W, Guo Y, Wang XH, He W, Wan X, Sun F, Wei Q, Chen C, Pan G, Xia J, Mao Q, Chen Y, Deng G (2020c): Viral kinetics and an- 
tibody responses in patients with COVID-19. medRxiv (preprint). https://doi.org/10.1101/2020.03.24.20042382

Tang N, Li D, Wang X, Sun Y (2020): Abnormal coagulation parameters are associated with poor prognosis in patients with novel coronavirus pneumonia. J. Thromb. Haemost. 18(4), 844-847. https://doi.org/10.1111/ jth. 14768

Toscano G, Palmerini F, Ravaglia S, Ruiz L, Invernizzi P, Cuzzoni MG, Franciotta D, Baldanti F, Daturi R, Postorino P, Cavallini A, Micieli G (2020): Guillain-Barré syndrome associated with SARS-CoV-2. N. Engl. J. Med. 382(26), 2574-2576. https://doi.org/10.1056/NEJMc2009191

US Food and Drug Administration (2020): Coronavirus (COVID-19) update: FDA authorizes first antigen test to help in the rapid detection of the virus that causes COVID-19 in patients. Available from https://www. fda.gov/emergency-preparedness-and-response/ counterterrorism-and-emerging-threats/coronavirusdisease-2019-covid-19. [Last accessed on 2020 June 04].

Vashisht SK (2020): In vitro diagnostic assays for COVID-19: Recent advances and emerging trends. Diagnostics.10(4), 202. https://doi.org/10.3390/diagnostics10040202

Wang D, Hu B, Hu C, Chang Hu C, Zhu F, Liu X, Zhang J, Wang B, Xiang H, Cheng Z, Xiong Y, Zhao Y, Li Y, Wang X, Peng Z (2020): Clinical characteristics of 138 hospitalized patients with 2019 novel coronavirus-infected pneumonia in Wuhan, China. JAMA 323(11), 1061-1069. https://doi.org/10.1001/jama.2020.1585

WHO (2020a): Coronavirus disease (COVID-19) technical guidance: laboratory testing for 2019-nCoV in humans. Available from: https://www.who.int/emergencies/ diseases/novel-coronavirus-2019/technical-guidance/ laboratory-guidance (Updated on March 2, 2020). https://doi.org/10.1016/j.bsheal.2020.02.001

WHO (2020b): Global surveillance for COVID-19 caused by human infection with COVID-19 virus. 2020. Available from: https://www.who.int/docs/defaultsource/coronaviruse/2020-03-20-surveillance. pdf?sfvrsn=e6be6ef1_2.

WHO (2020c): Protocol to investigate non-seasonal influenza and other emerging acute respiratory diseases. Geneva: World Health Organization; 2018. Available from:https://www.who.int/influenza/resources/publications/outbreak_investigation_protocol/en/). [Last accessed on 2020 June 04]

Wu Z, McGoogan JM (2020): Characteristics of and important lessons from the coronavirus disease 2019 (COVID-19) outbreak in China: Summary of a report of 72314 cases from the Chinese center for disease control and prevention. JAMA 323(13), 1239-1242. https://doi. org/10.1001/jama.2020.2648

Xia W, Shao J, Guo Y, Peng X, Li Z, Hu D (2020): Clinical and CT features in pediatric patients with COVID-19 infection: different points from adults. Pediatr. Pulmonol.55(5), 1169-1174. https://doi.org/10.1002/ppul.24718

Xie J, Tong Z, Guan X, Du B, Qiu H, Slutsky AS (2020): Critical care crisis and some recommendations during the COVID-19 epidemic in China. Intensive Care Med. 46, 837-840. https://doi.org/10.1007/s00134-020-05979-7

Xu XW, Wu XX, Jiang XG, Xu KJ, Ying LJ, Ma CL, Li SB, Wang HY, Zhang S, Gao HN, Sheng JF, Cai HL, Qiu YQ, Li LJ (2020): Clinical findings in a group of patients infected with the 2019 novel coronavirus (SARS-Cov-2) outside of Wuhan, China: Retrospective case series. BMJ 368, m606. https://doi.org/10.1136/bmj.m606

Zhao D, Yao F, Wang L, Zheng L, Gao Y, Ye Z, Gao F, Zhao H, Gao $R$ (2020): A comparative study on the clinical features of COVID-19 pneumonia to other pneumonias. Clin. Infect. Dis. ciaa247.https://doi.org/10.1093/cid/ciaa247

Zheng Z, Peng F, Xu B, Zhao Z, Huahua Liu, H, Peng J, Li Q, Jiang C, Zhou Y, Liu S, Ye, C, Zhang P, Xing Y, Guo H, Tang W (2020): Risk factors of critical \& mortal COVID-19 cases: A systematic literature review and meta-analysis. J. Infect. 81(2), e16-e25. https://doi.org/10.1016/j. jinf.2020.04.021

Zhou P, Yang XL, Wang XG, Hu B, Zhang L, Zhang W, Si HR, Zhu Y, Li B, Huang CL, Chen HD, Chen J, Luo Y, Guo H, Jiang RD, Liu MQ, Chen Y, Shen XR, Wang X, Zheng XS, Zhao K, Chen QJ, Deng F, Liu LL, Yan B, Zhan FX, Wang YY, Xiao GF, Shi ZL (2020): A pneumonia outbreak associated with a new coronavirus of probable bat origin, Nature 579, 270-273. https://doi.org/10.1038/ s41586-020-2012-7 